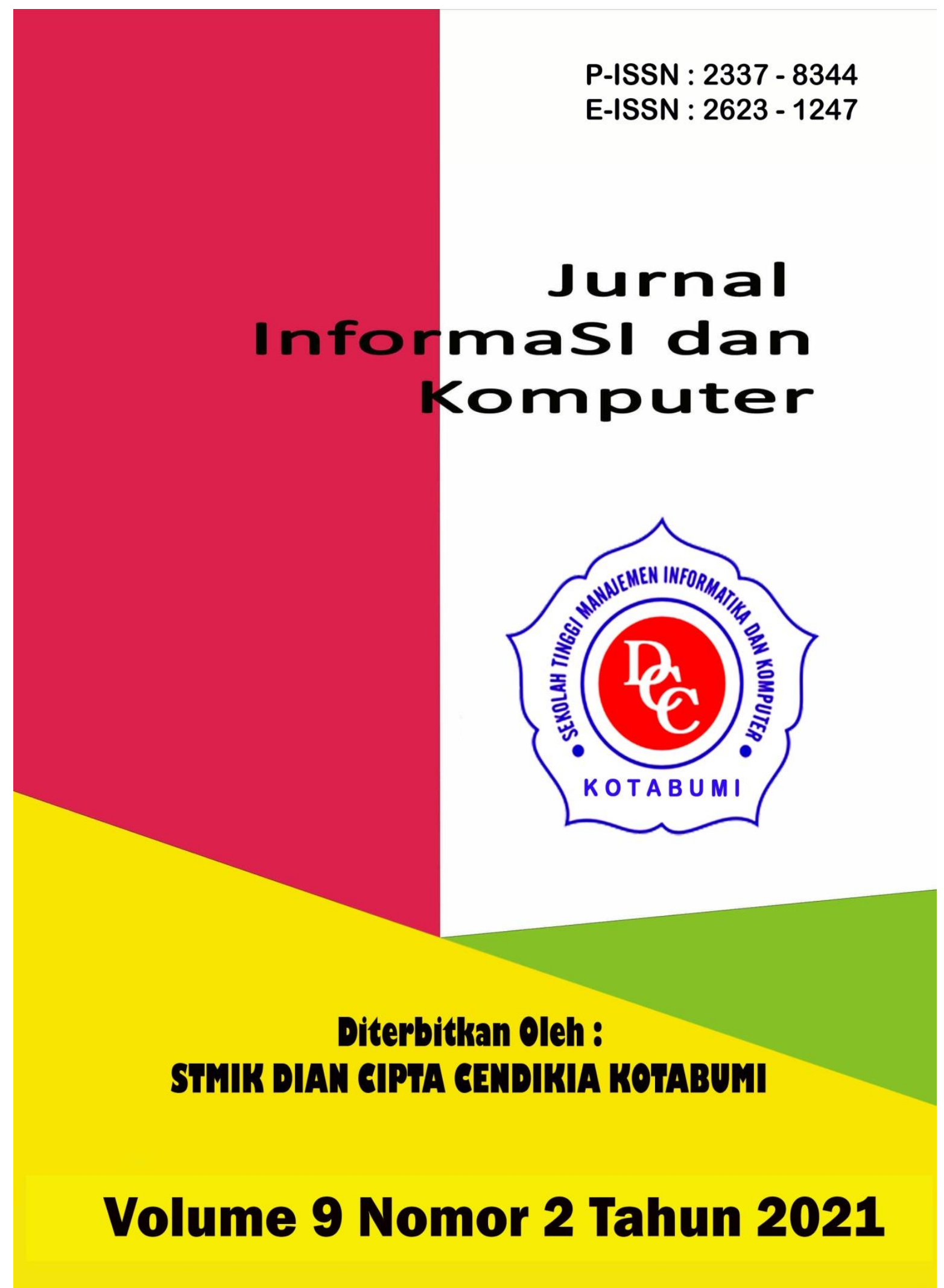




\section{Penerbit}

\section{Lembaga Penelitian STMIK Dian Cipta Cendikia Kotabumi}

Hak atas naskahh/tulisan tetap berada pada penulis, isi diluar tangung jawab penerbit dan Dewan Penyunting 


\section{PENGANTAR REDAKSI}

Puji syukur dipanjatkan kehadirat Tuhan Yang Maha Esa, atas karunia dan limpahan rahmatNYA jualah Jurnal Informasi dan komputer (JIK) STMIK Dian Cipta Cendikia Kotabumi ini dapat terwujud.Jurnal Informasi dan Komputer (JIK) yang terbit dua (2) kali dalam setahun ini merupakan suatu wadah untuk penyebar luasan hasil-hasil penelitian, studi pustaka, karya ilmiah yang berkaitan dengan Informasi dan Komputer khususnya bagi dosen-dosen STMIK Dian Cipta Cendikia Kotabumi serta umumnya para cendikiawan, praktisi, peneliti ilmu Informatika dan Komputer.

Harapan, dengan diterbitkannya Jurnal Informasi dan Komputer (JIK) ini sebagai salah satu bentuk sumbangan pemikiran dalam pengembangan ilmu informatika dan komputer yang berkaitan dengan kajian-kajian di bidang tekhnologi Informatik, Komunikasi Data dan Jaringan Komputer, perancangan dan Rekayasa Perangkat Lunak, serta ilmu-ilmu yang terkait dengan bidang Informasi dan Komputer lainnya.

Berkenaan dengan harapan tersebut, kepada para peneliti, dosen dan praktisi yang memiliki hasil-hasil penelitian, kajian pustaka, karya ilmiah dalam bidang tersebut diatas, dengan bangga redaksi Jurnal Informasi dan Komputer (JIK) menerima naskah ringkasan untuk dimuat pada jurnal Informasi dan Komputer (JIK) STMIK Dian Cipta Cendikia Kotabumi dengan berpedoman pada penulisan naskah jurnal sebagaimana dilampirkan pada halaman belakang (Bagian kulit dalam) buku jurnal ini.

Mutu dari suatu jurnal ilmiah tidak hanya ditentukan oleh para pengelolanya saja, tetapi para penulis dan pembaca jualah yang mempunyai peranan besar dalam meningkatkan mutu jurnal Informatika dan Komputer ini. Merujuk pada realita ini kamu sangat mengharapkan peran aktif dari peneliti untuk bersama-sama menjaga dan memelihara keberlangsungan dari jurnal Informasi dan Komputer STMIK Dian Cipta Cendikia Kotabumi ini. Yang juga tidak kalah pentingnya dari partisipasi tersebut diatas, adalah saran dan kritik yang membangun dari pembaca yang budiman agar kiranya dapat disampaikan langsung kepada redaksi JIK. Saran dan kritik yang membangun akan dijadikan masukan dan pertimbangan yang sangat berarti guna peningkatan mutu dan kualitas Jurnal Informasi dan Komputer STMIK Dian Cipta Cendikia Kotabumi.

Tak lupa diucapkan terima kasih yang tak terhingga atas perhatian dan kerjasama dari semua pihak yang tak dapat disebutkan satu persatu hingga dapat diterbitkan nya Jurnal Informasi dan Komputer (JIK) STMIK Dian Cipta Cendikia Kotabumi. Semoga apa yang telah diperbuat untuk kebaikan akan menjadi amal ibadah, amin.

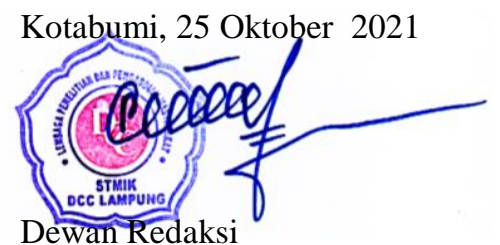




\section{JURNAL INFORMASI DAN KOMPUTER}

Volume 9 Nomor 2 Oktober 2021

Jurnal Informasi dan Komputer merupakan Sarana informasi ilmu pengetahuan, Tekhnologi dan Komunikasi yang berupa hasil penelitian, tulisan ilmiah, Ataupun studi pustaka. Jurnal ini terbit dua kali setahun pada bulan April dan Oktober. Berisi hasil penelitian ilmiah di bidang informatika yang bertujuan untuk menghubungkan adanya kesenjangan antar kemajuan teknologi dan hasil penelitian. Jurnal ini di terbitkan pertama kali pada tahun 2013.

Penanggung Jawab:

Ketua STMIK Dian Cipta Cendikia Kotabumi

\section{Pembina:}

Ketua STMIK Dian Cipta Cendikia Kotabumi Ketua Lembaga Penelitian STMIK Dian Cipta Cendikia Kotabumi

\section{Pimpinan Redaksi}

Dwi Marisa Efendi,.S.Kom.,M.Ti

\section{Redaksi pelaksana}

Rustam,.S.Kom,.M.Ti (STMIK Dian Cipta Cendikia Kotabumi)

Nurmayanti M.Kom (STMIK Dian Cipta Cendikia Kotabumi)

Sukatmi,.S.Kom., M.Kom (AMIK DCC Bandar Lampung)

Sampurna Dadi Riskiono,M.Kom (Universitas Teknokrat Indonesia)

Ifo Wahyu Pratama,S.Kom.,M.Ti(AMIK MASTER Lampung)

\section{Mitra Bestari}

Dr. RZ. ABDUL AZIZ, ST., MT (Institut Informatika dan Bisnis Darmajaya)

Dr. Dadang Sudrajat, S.Si, M.Kom (STMIK IKMI Cirebon)

Dr. Septafiansyah Dwi Putra, S.T., M.T (Politeknik Negeri Lampung)

Dr. Evi Grativiani, S.E., M.S.I (Universitas Sebelas Maret)

Rohmat Indra Borman ( Universitas Teknokrat Indonesia )

Ferry Wongso, S.KOm., M.Kom ( STMIK Darma Pala Riau)

Ferly Ardhy, S.Kom., M.Ti ( Universitas Aisyah Pringsewu )

Firmansyah, S.E., M.Si (STMIK Darma Pala Riau)
Amarudin (Universitas Teknokrat Indonesia)

Didi Susianto, S.T., M.Kom (AMIK Dian Cipta Cendika Bandar Lampung)

Alhibarsyah, St., M.Kom (STMIK Tunas

Bangsa Bandar Lampung)

Kemal Farouq Mauladi, S.Kom .M.Kom (Universitas Islam Lamongan)

Rima Mawarni, M.Kom ( STMIK Dian Cipta Cendikia Kotabumi)

Wira Jaya Hartono, S.Pd., M.Pd ( STMIK Darma Pala Riau)

Penerbit : STMIK Dian Cipta Cendikia Kotabumi Bekerja Sama Dengan LPPM STMIK Dian Cipta Cendikia Kotabumi.

\section{Alamat Redaksi/Penerbit:}

Jl. Negara No. 3 Candimas Kotabumi Lampung Utara

No Telpon/Fax 072423003

Email : 1ppm-stmik@dcc.ac.id 


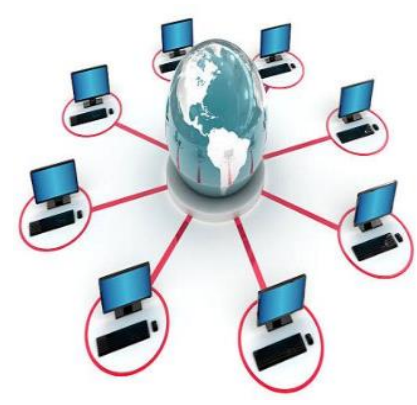

\section{JURNAL INFORMASI DAN KOMPUTER VOL. 9 NO. 2 THN. 2021}

\section{DAFTAR ISI}

Halaman

Sistem Informasi Akuntansi Persedian Barang Berbasis Web Pada Lembaga

Permasyarakatan Kelas II A Banceuy Bandung : "Kelompok Tani Desa Banjar Kertarahayu” Teuku Rian Hardiyansyah, Fatia Salsa Azzahra (Politeknik Piksi Ganesha Bandung ${ }^{1,2}$ ).

Penerapan Finite State Automata Pada Vending Machine Penjual Obat Non Resep

Dokter Dan Keperluan Medis

Eko Supriyanto $^{1}$, Angga Ardiansyah ${ }^{2}$, Frieyadie $^{3}$, Sri Rahayu ${ }^{4}$, Windu Gata ${ }^{5}$

(Universitas Nusa Mandiri ${ }^{12}$ )

Sistem Pendukung Keputusan Untuk Menentukan Kelayakan Pengajuan Sertifikasi Guru Dengan Metode Simple Additive Weighting (Studi Kasus : Ma Al Muhajirin Janti Jogoroto Jombang)

Budiman, umam baharudin, winarti

(Universitas Darul 'Ulum Jombang)

Perancangan Infrastruktur Domain Name Server Lokal Menggunakan Ubuntu Server 16.04

Pada PT. Xyz

Zaenal Mutaqin Subekti, Hendra Setiawan, Satria, Widia Murni Wijaya,

Aliy Hafiz, Warsudi

(STMIK Bani Saleh, Universitas Negeri Yogyakarta, AMIK Dian Cipta Cendikia,

STMIK MIC CIkarang)

Perancangan Sistem Informasi Idea Proposal (Ip) Berbasis Web Pada Pt. Paxel Algorita Unggul

Julian Murhan Sahputra, Indah Purnamasari

(Universitas Nusa Mandiri ${ }^{12}$ )

Sistem Pendukung Keputusan Untuk Menentukan Ekstrakurikuler Atletik

Berdasarkan Bakat Siswa Menggunakan Metode Profile Matching

Agnes Basuki, Petrus Sokibi, Tiara Eka Putri

(Universitas Catur Insan Cendekia)

Penerapan Algoritma K-Means Untuk Pengelompokan Usia Calon Penerima Vaksin

Di Kab. Ngawi

Irna Yuniarfi, Saifulloh

(Universitas PGRI Madiun ${ }^{12}$ )

System Penilaian Seleksi Calon Karyawan Baru Menggunakan Metode Simple Additive Weighting (SAW) Di PT.TNA

Anik Sri Wahyuningsih, Yudhi Firmansyah

(Universitas Panca Sakti Bekasi ) 
Perancangan Sistem Informasi Pembayaran SPP Menggunakan Framework Laravel Ichwan Habib Moudi

(Universitas Panca Sakti Bekasi)

Implementasi Algoritma K-Means Dan Algoritma Apriori Optimasi Kinerja Ecu

(Study Kasus Mobil Avanza Dan Xenia)

Sigit Mintoro' Asep Afandi

(STMIK Dian Cipta Cendikia Kotabumi)

Sistem Pakar Penyakit Buah Kakao Untuk Peningkatan Hasil Panen Kakao Menggunakan

Metode Case Base Reasoning (CBR) Berbasis Web Mobile

Aliy hafiz, Verawati

(AMIK Dian Cipta Cendikia,Bandar Lampung)

Penerapan Metode Rapid Application Develomment (RAD) Dalam Pengembangan

Sistem Pemesanan Menu Berbasis Android

Aris Baihaqi, Tumini

(Fakultas Sains dan Teknologi ${ }^{1,2}$ ).....

Rancang Bangun Sistem Informasi Geografis Pariwisata Di Lampung Timur

Sukatmi, Rexa Alfa Rizi

(AMIK DCC Bandar Lampung ${ }^{12}$ )

Implementasi Psak No. 45 Pada Proses Penyusunan Laporan Keuangan Menggunakan

M.S. Excel Dan Aplikasi Accurate Accouting Pada STMIK Bani Saleh

Marhakim, Willy Adam

(STMIK Bani Saleh ${ }^{12}$ )

Sistem Prediksi Harga KOPI LAMBAR ( Lampung Barat) Dengan Metode

Backpropagation, dan Double Exponential ( Studi Kasus BUMDES )

Supriyanto, Dwi marisa Efendi,Rhomadhon

(STMIK Dian Cipta cendikia Kotabumi ${ }^{1-}$ )

Sistem Informasi Pemasaran Produk Umkm Berbasis Web Pada Kecamatan Bumi

Nabung Lampung Tengah

Yuli Syafitri, Agus Prasetyo, Reni Astika

(AMIK Dian Cipta Cendikia Bandar Lampung)

Rancang Bangun Aplikasi Pembelajaran Aksara Lampung Berbasis Android

Ferly Ardhy, Hendra Syahrobi

(Universitas Aisyah Pringewu ${ }^{1,}$ STMIK Dian Cipta Cendikia ${ }^{2}$ )

Sistem Pakar Diagnosa Penyakit Kulit Pada Balita Menggunakan Metode Naïve

Bayes Dan Forward Chaining Studi Kasus Puskesmas Cempaka Sungkai Selatan

Sidik Rahmatullah, Rima Mawarni

(STMIK Dian Cipta Cendikia Kotabumi ${ }^{12}$ )

Rekayasa Perangkat Lunak Perhitungan Harga Pokok Produksi Metode

Full Costing Pada Umkm Mitra Cake Di Bandar Lampung

Pitrawati, Arif Sanjaya

(AMIK Dian Cipta Cendikia, Bandar Lampung) 
Rancang Bangun Sistem Ujian Online Menggunakan Algoritma Cosine Similarity

Berbasis Web

Haryono, Zaenal Mutaqin Subekti, Widiyawati, Hidayatullah

(STMIK Bani Saleh ${ }^{1234}$ )

Model Aplikasi Helpdesk Ticketing System Berbasis Web Menggunakan Metode Rad

Indra Permana

Pattern Recognition Tulisan Tangan Huruf Hijaiyah Menggunakan Metode

Convolutional Neural Network (CNN)

Mufassiril Abror, Nopiyanto

(Universitas Panca Sakti Bekasi ${ }^{12}$ )

Aplikasi Sistem Informasi Keuangan Berbasis Android Di Perumahan Taman

Karang Bahagia

Melda Ayulestari

(Universitas Panca Sakti Bekasi)

Audit Pelayanan Sistem Rujukan Online Puskesmas Menggunakan Framework COBIT 5.0

Nurmayanti, Merri Parida, Ngajiyanto, Ina Anzalna

(STMIK Dian Cipta Cendikia Kotabumi ${ }^{1234}$ )

Perancangan Sistem Informasi Pengolahan Data Nilai Siswa Berbasis Web

Erin Ermawati, Anik Sri Wahyuningsih

(Fakultas Sain dan Teknologi, Universitas Panca Sakti Bekasi ${ }^{12}$ )

Pengembangan Sistem Pelaporan Data Hasil Inspeksi Barang Berbasis Web

Siska Putriani

(Universitas Pancasakti Bekasi)

Penerapan Extreme Programming Dalam Perancangan Aplikasi Web Food Market

Tumini, Hilman Septiana

(Fakultas Sains dan Teknologi Universitas Panca Sakti Bekasi ${ }^{1,2}$ )

Sistem Pencarian Barang Berbasis Website Menggunakan Php Dan Mysql

Studi Kasus PT. Surya Technology Industri Sulaeman

(Universitas Panca Sakti Bekasi)

Implementasi Metode Prototype Pada Sistem Peminjaman Alat Kerja Berbasis Web

Di PT SK Metalindo

Ali Mulyanto, Arjun Gunawan

(Univeritas Panca Sakti Bekasi)

Aplikasi Tata Cara Wudhu Menggunakan Teknologi Augmented Reality

Sebagai Media Pembelajaran Di TK Al Fatih

Ahmad Yakub , Idarul Fadli

(Universitas Panca Sakti Bekasi ${ }^{12}$ )

Sistem Pakar Diagnosa Penyakit Ayam Petelur Menggunakan Metode Certainty Factor

Berbasis Web Mochammad

Taufiq Hidayat, Ali Mulyanto

(Universitas Panca Sakti Bekasi ${ }^{12}$ ) 
Penerapan Metode Prototyping Dalam Perhitungan Hasil Produksi Menggunakan

Arduino Uno R3 Dan Php Di PT. Indonesia Epson Industry

Amandha Aulia, Ajar Rohmanu

(Universitas Panca Sakti Bekasi ${ }^{12}$ )

System Pendukung Keputusan Penentuan Guru Teladan Dengan Metode Profile Matching

Hasbulloh, Agmawarnida

(Universitas Panca Sakti Bekasi ${ }^{1,2}$ )

Implementasi Waterfall Method Pada Aplikasi Buku Induk Siswa Berbasis Web

Idam Holid, Yogie Krisnayadi

(Universitas Panca Sakti ${ }^{12}$ )

Pengembangan Text To Speech Media Pembelajaran Untuk Pengenalan

Anggota Tubuh Manusia Kelas V Sekolah Dasar

Juwanda Saputra, Ali Mulianto

(Teknik Infomratika Fakulutas Sains dan Teknologi ${ }^{12}$ )

Perancangan Sistem Peminjaman Barang Berupa Aset Tetap Berbasis Web

Pada Lembaga Permasyarakatan Kelas II A Banceuy Bandung

Guntur Salasa Priambodo, Perwito, Candra Mecca Sufyana

(Politeknik Piksi Ganesha Bandung ${ }^{1,2,3}$ )

Metode Pemilihan Karyawan Terbaik Sebagai Penentu Goodwill Perguruan Tinggi

Dengan Menggunakan Metode Topsis (Studi Kasus Perguruan Tinggi Di Lampung Utara)

Dwi Sartika, Pakarti Riswanto

(STMIK Dian Cipta Cendikia Kotabumi)

Sistem Pendukung Keputusan Pemilihan Merek Smartphone Menggunakan

Metode Analytical Hierarchy Process (AHP)

Ade Kiki Fatmawati, Muhammad Sultan Raflie, Norma Yunita

(Universitas Nusa Mandiri ${ }^{123}$ )

Pattern Recognition Aksara Lampung Menggunakan Algoritma Neural Network

Metode Analytical Hierarchy Process (AHP)

Nopiyanto, Rahmadi

(Universitas Panca Sakti Bekasi) 


\title{
IMPLEMENTASI METODE PROTOTYPE PADA SISTEM PEMINJAMAN ALAT KERJA BERBASIS WEB DI PT SK METALINDO
}

\author{
Ali Mulyanto ${ }^{1}$, Arjun Gunawan ${ }^{2}$ \\ Univeritas Panca Sakti Bekasi \\ Jl. Kapten Sumantri No. 16, Cikarang Pusat, Kabupaten Bekasi \\ E-mail: alimulyanto.psub@gmail.com, arjungunawan845@gmail.com
}

\begin{abstract}
ABSTRAK
Penerapan metode dalam pengembangan aplikasi peminjaman alat kerja berbasis web merupakan hal yang penting dalam menilai keberhasilan aplikasi tersebut apakah berjalan sesuai perencanaan dan telah memenuhi kebutuhan dari penggunanya. Penelitian ini akan memberikan gambaran metode prototype pada pengembangan aplikasi peminjaman alat kerja berbasis web. Prototype dibuat dengan tujuan memberikan penyamaan persepsi dan pemahaman awal dari sistem yang akan dikembangkan, sehingga akan ada komunikasi yang baik antara pengembang dan pengguna sistem. Aplikasi yang akan dibuat berbasis web dengan menggunakan framework Laravel. Penggunaan Laravel diharapkan mampu memudahkan pembuatan aplikasi peminjaman alat kerja berbasis web, sehingga peningkatan mutu pengelolaan alat kerja semakin baik.
\end{abstract}

Kata kunci: Prototype, Sistem Berbasis Web, Aplikasi

\begin{abstract}
Method implementation in web-based work tools loan application development is important in assessing the success of the application whether it is running according to plan and has met user requirement. This research will provide an overview of the prototype method in web-based work tools loan application development. The prototype is made with the aim of providing a common perception and initial comprehension from the system will be developed, so that there will be good communication between developer with users. The application to be made web-based with using Laravel framework. The use of Laravel is expected to make it easier to create web-based work tools loan application, so that quality improvement and work tools management be better.
\end{abstract}

Keywords: Prototype, Web-based system, application

\section{PENDAHULUAN}

Perkembangan teknologi informasi yang semakin pesat menjadi tantangan bagi sebuah perusahaan baik itu Badan Usaha Milik Negara (BUMN) maupun swasta. Teknologi informasi adalah seperangkat alat yang membantu perusahaan untuk bekerja dengan sistem dan melakukan tugas-tugas yang berhubungan dengan pemrosesan informasi secara digital guna tercapai visi dan misi perusahaan tersebut. Sistem adalah kumpulan atau himpunan dari unsur atau variabel-variabel yang saling terkait, saling berinteraksi, dan saling tergantung satu sama lain untuk mencapai tujuan (Tohari, 2014) Salah satunya yaitu sistem peminjaman alat kerja berbasis web, sistem ini berfungsi sebagai sarana untuk mencatat data peminjaman alat kerja oleh karyawan sehingga menunjang kelancaran dalam pengelolaan alat kerja.

Sistem peminjaman alat kerja yang sudah ada di PT. SK Metalindo masih menggunakan cara manual, yaitu admin gudang mencatat kode alat kerja dan nama karyawan peminjam di buku catatan sesuai dengan ketentuan tanggal pada saat meminjam dan mencoret data alat kerja menggunakan stabilo pada saat karyawan telah 
mengembalikan alat tersebut ke gudang. Hal yang sering terjadi adalah penulisan di buku catatan tidak rapi dan kurang terstruktur sehingga seringkali membingungkan admin gudang lainnya.

\section{METODE PENELITIAN}

Pada penelitian ini, masalah yang diteliti yaitu peminjaman alat kerja yang masih manual kemudian dikembangkan menjadi sistem peminjaman alat berbasis web dengan menggunakan metode prototipe.

\subsection{Tahapan-tahapan proses pengembangan sistem.}

Menurut Raymond McLeod (2011), "prototype didefinisikan sebagai alat yang memberikan ide bagi pembuat maupun pemakai potensial tentang bagaimana sistem berfungsi dalam bentuk lengkapnya, dan proses untuk menghasilkan sebuah prototype disebut prototyping". Prototyping adalah proses pembuatan model sederhana software yang mengizinkan pengguna memiliki gambaran dasar tentang program serta melakukan pengujian awal. Prototyping memberikan fasilitas bagi pengembang dan pemakai untuk saling berinteraksi selama proses pembuatan, sehingga pengembang dapat dengan mudah memodelkan perangkat lunak yang hendak dibuat. Berikut adalah tahapan-tahapan proses pengembangan model prototipe:

\section{Pengumpulan Kebutuhan}

Pelanggan dan pengembang bersama-sama mendefinisikan format seluruh perangkat lunak, mengidentifikasi semua kebutuhan, dan garis besar sistem yang akan dibuat.

\section{Membangun Prototyping}

Membangun prototyping dengan membuat perancangan sementara yang berfokus pada penyajian kepada pelanggan (misalnya dengan membuat input dan format output).

\section{Evaluasi Prototyping}

Evaluasi ini dilakukan oleh pelanggan, apakah prototyping yang telah dibangun sesuai dengan keinginan pelanggan. Jika sudah sesuai, maka langkah selanjutnya akan diambil. Namun jika tidak, prototyping direvisi dengan mengulang langkah-langkah sebelumnya.

\section{Pengkodean Sistem}

Dalam tahap ini prototyping yang sudah di sepakati diterjemahkan ke dalam bahasa pemrograman yang sesuai.

\section{Pengujian Sistem}

Setelah sistem telah menjadi suatu perangkat lunak yang siap pakai, kemudian dilakukan proses pengujian. Pengujian ini dilakukan dengan White Box, Black Box, Basis Path, pengujian arsitektur, dll.

\section{Evaluasi Sistem}

Pelanggan mengevaluasi apakah perangkat lunak yang sudah jadi sudah sesuai dengan yang diharapkan Jika ya, maka proses akan dilanjutkan ke tahap berikutnya, namun jika perangkat lunak yang sudah jadi tidak sesuai dengan apa yang diharapkan, maka tahapan sebelumnya akan diulang.

\section{Penggunaan Sistem}

Perangkat lunak atau sistem yang telah diuji dan diterima oleh pelanggan siap untuk digunakan.

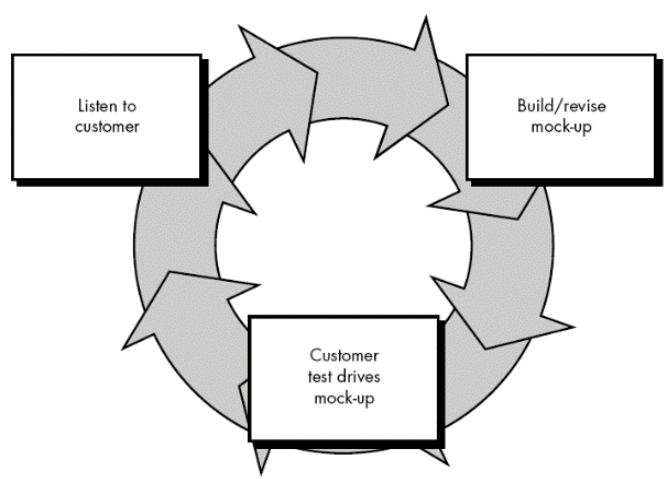

Gambar 1 Model Prototype (Khosrow-Pour, 2005)

\subsection{Metode Pengumpulan Data}

Metode pengumpulan data dan informasi yang diperlukan menggunakan cara sebagai berikut:

\section{Studi Pustaka}


Penulis mengumpulkan bahan referensi yang diperoleh dari buku, jurnal, situs dan tulisan yang relevan dengan materi sistem yang diteliti.

\section{Observasi}

Pada tahap ini dilakukan observasi untuk mendapatkan data dan permasalahan di lapangan selanjutnya dilakukan perumusan masalahnya.

\section{Interview}

Metode ini digunakan sebagai pengumpulan data dengan cara mengajukan berbagai pertanyaan kepada pihak perusahaan yang berhubungan dengan pembuatan sistem. Penulis melakukan interview dengan kepala gudang penyimpanan alat kerja di PT. SK Metalindo.

\subsection{Tempat Penelitian}

Penelitian dilaksanakan di PT. SK Metalindo yang beralamat di Jl. Raya Lemahabang No. 59 Cikarang Timur, Bekasi, Jawa Barat.

\subsection{Waktu Penelitian}

Waktu penelitian dilakukan dari bulan Juni sampai Agustus 2021.

\section{HASIL DAN PEMBAHASAN}

Pada tahapan ini merupakan kegiatan implementasi sistem atau aplikasi dengan bantuan software maupun hardware sesuai dengan analisis dan perancangan untuk menghasilkan suatu sistem yang bekerja. Selanjutnya sistem dibuat dalam bentuk prototipe kemudian dilakukan uji coba dan evaluasi untuk mengetahui sistem yang dibuat sesuai dengan yang diinginkan.

\section{a. Tampilan Login}

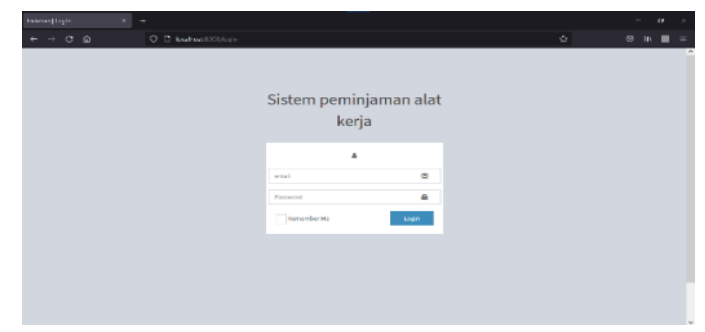

Gambar 2. Halaman Login
Halaman login berisi form input email dan password. Jika email dan password yang diinput salah sistem akan menolak dan tetap menampilkan halaman login, jika email dan password benar maka tampil halaman dashboard.

\section{b. Halaman Dashboard}

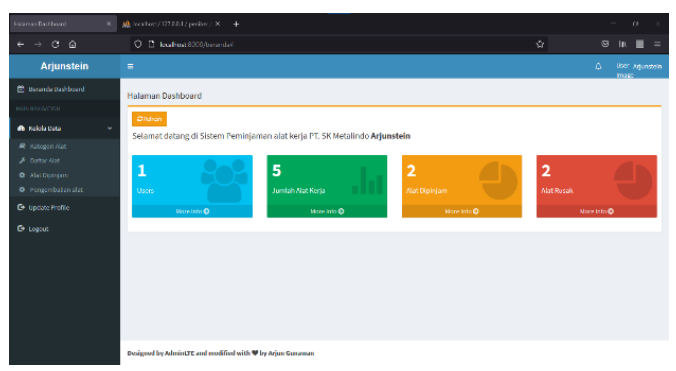

Gambar 3. Halaman Dashboard

Halaman dashboard berisi tampilan data alat kerja yang dikelola oleh admin seperti total users, jumlah alat kerja, jumlah alat yang dipinjam, jumlah alat yang rusak

\section{c. Halaman Kategori Alat}

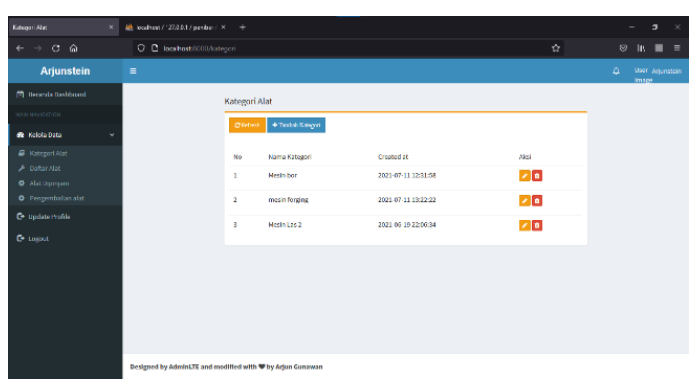

Gambar 4. Halaman Kategori Alat

Halaman ini dikelola oleh admin berisi daftar kategori alat atau jenis mesin yang digunakan dalam proses kerja.

\section{d. Halaman Kelola Alat Kerja}

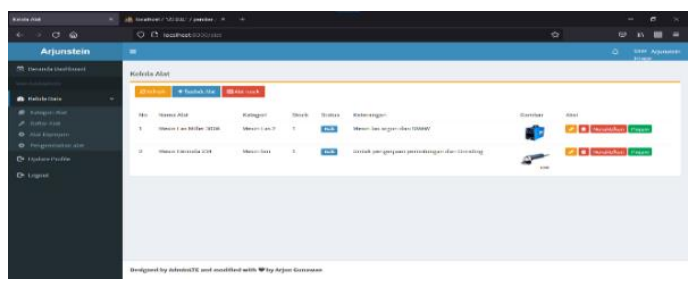

Gambar 5. Halaman Kelola Alat Kerja 
Halaman ini dikelola oleh admin berisi daftar alat kerja, kategori, dan statusnya. Admin bisa melakukan create, read, update, delete (CRUD) serta input peminjaman alat.

\section{e. Halaman Tambah Data Alat}

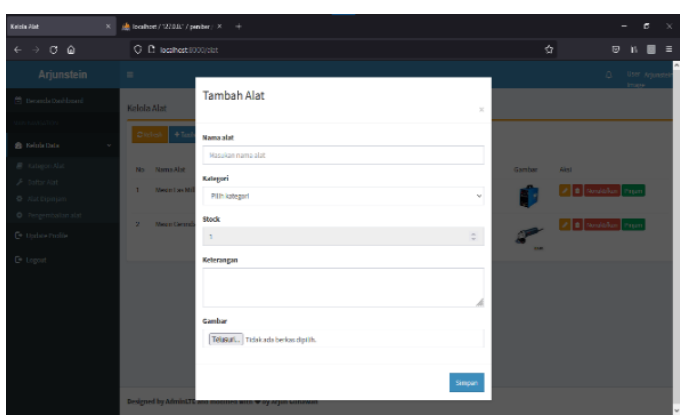

Gambar 6. Halaman Buat Data Alat

Halaman ini dikelola oleh admin berisi form input tambah alat kerja.

\section{f. Halaman Alat Dipinjam}

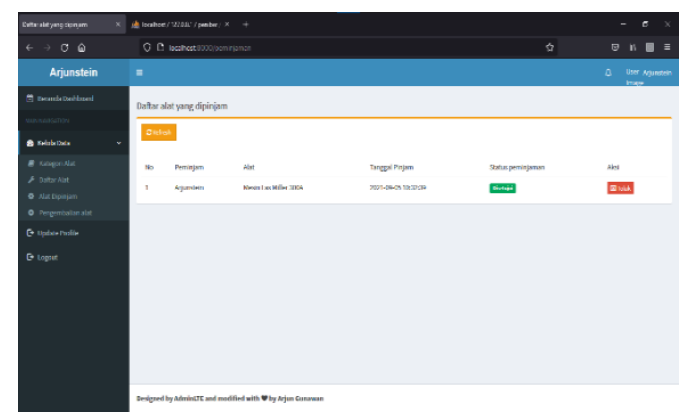

Gambar 7. Halaman Alat Dipinjam

Halaman ini berisi konfirmasi peminjaman oleh admin dan terdapat daftar alat kerja, nama user, tanggal peminjaman, status peminjaman.

\section{g. Halaman Pengembalian Alat}

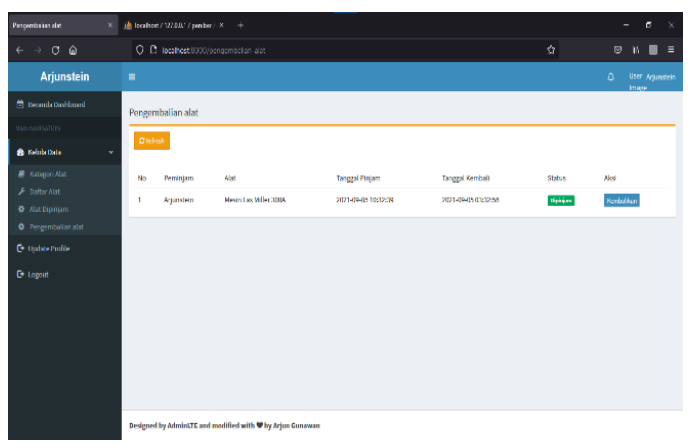

Gambar 8. Halaman Pengembalian Alat
Halaman ini berisi daftar nama user, nama alat yang dipinjam, tanggal peminjaman, tanggal pengembalian, status peminjaman, dan terdapat button yang hanya bisa diklik oleh admin untuk pengembalian alat kerja setelah selesai digunakan.

\section{KESIMPULAN}

Adapun beberapa simpulan yang dapat dipetik untuk sistem peminjaman alat kerja berbasis web ini sebagai berikut:

a. Sistem yang dibuat memudahkan admin gudang dalam mengelola data alat kerja, kondisi alat kerja, dan pengelolaan laporan.

b. User lebih mudah dalam mengetahui alat kerja dan kondisi alat kerja yang dipinjam.

Adapun beberapa saran yang dapat disampaikan untuk sistem peminjaman alat kerja berbasis web sebagai berikut:

a. Perlu adanya koneksi internet yang stabil agar sistem berjalan optimal.

b. Bagi perusahaan, dapat dijadikan bahan masukan untuk lebih memanfaatkan perkembangan teknologi informasi dalam meningkatkan kinerja karyawan dan manajemen mutu.

c. Bagi peneliti, dapat dijadikan masukan sebagai bahan pertimbangan untuk melakukan penelitian-penelitian serupa.

\section{DAFTAR PUSTAKA}

[1]. Setiyawan, A. (2013). "Pembuatan Sistem Informasi Akademik Berbasis Web." Indonesian Journal On Networking And Security - ISSN: 2302-5700, 2. Tohari, H. (2014). Astah. Madiun: Andi.

[2]. McLeod, Jr., Raymond; Schell, George P. 2011. Sistem Informasi Managemen

(Terjemahan). Jakarta: Salemba Empat.

[3]. Wahyu Wijaya. W (2018). "Analisa Metodologi Pengembangan Sistem Dengan Perbandingan Model Perangkat Lunak Sistem Informasi Kepegawaian Menggunakan Waterfall Development Model, 
Model Prototype, Dan Model Rapid Application Development." Jurnal INFORMA Politeknik Indonusa Surakarta ISSN: 2442-7942 Vol. 4 Nomor 1 Tahun 2018.

[4]. Helpi Nopriandi (2018). "Perancangan Sistem Informasi Registrasi Mahasiswa." Jurnal Teknologi Dan Open Source Vol. 1 No. 1, Juni 2018 ISSN Online: 2622-1659.

[5]. M. Rizky Alpiandi (2016). "Sistem Informasi Akademik Berbasis Web Di Smp Negeri 2 Kecamatan Gaung Anak Serka." Jurnal SISTEMASI, Volume 5, Nomor 3, September 2016: 8 - 13 E-ISSN: 2540-9719 ISSN: 2302-8149.

[6]. Dwi Purnomo (2017). "Model Prototyping Pada Pengembangan Sistem Informasi." JIMP - Jurnal Informatika Merdeka Pasuruan Vol.2 No.2 Agustus 2017 ISSN 2503-1945

[7]. Nugraha, W., \& Syarif, M (2018). JUSIM (Jurnal Sistem Informasi Musirawas) Wahyu Nugraha, Muhamad Syarif Vol 03 No.02, Desember 2018.

[8]. Ferry Susanto (2018). "Sistem Informasi Pengolahan Data Pasien Pada Puskesmas Abung Pekurun Menggunakan Metode Prototype." Jurnal Mikrotik Vol. 8/No. 1/Juli 2018 E-ISSN: 2443-4027 | P-ISSN: 2354-7006.

[9]. Budi Sudrajat (2021). "Penerapan Metode Prototype Sistem Informasi Peminjaman Ruang Meeting." Riset dan E-Jurnal Manajemen Informatika Komputer Volume 5, Number 2, April 2021 http://doi.org/10.33395/remik.v4i1. 10873 | e-ISSN: 2541-1330 pISSN: 2541-1332.

[10]. Rahmad, B, Mhd., \& Setiady, T (2014). "Perancangan Sistem Informasi Inventory Spare Part Elektronik Berbasis Web Php (Studi CV.
Human Global Service

Yogyakarta)." Jurnal Sarjana Teknik Informatika e-ISSN: 23385197 Volume 2 Nomor 2, Juni 2014 